\title{
REFORMULASI PENDEKATAN PENDIDIKAN ISLAM DALAM PROBLEM KONTEMPORER
}

\author{
A6dul Malik Karim Amrullah \\ UIN Maulana Malik Ibrahim Malang \\ Email: amkamutia@gmail.com
}

\begin{abstract}
There are at least three crucial issues to cover in Islamic education. First is humanitarian crisis. Second, is the issue of nature. The third is the crisis of divinity. This paper aims to demonstrate that the approach developed in Islamic education contributes to solve the three major problems. The development of Islamic education curriculum should be directed to the rescue of human nature that emphasizes its approach to morality so that human are able to think and act with full of wisdom. Therefore, preparing the curriculum or Islamic education program could start from the problems faced in the community as an educational content, while the process or the learning experience is developed by studying the Quran and the hadith. Learners should be able to reflect the results of the dialogue between Quran and hadith with the reality that occurs in the community.
\end{abstract}

Di dunia sekarang ini setidaknya ada tiga masalah krusial yang harus diperhatikan dalam pendidikan Islam. Pertama, adalah krisis kemanusiaan. Kedua, adalah masalah alam. Yang ketiga adalah krisis ketuhanan. Tulisan ini bertujuan menunjukkan bahwa pendekatan yang dikembangkan dalam pendidikan Islam ikut andil dalam menyelesaikan tiga problem besar tersebut. Pengembangan kurikulum pendidikan Islam harus diarahkan pada penyelamatan fitrah manusia yang lebih menekankan pendekatannya kepada akhlak agar manusia mampu berpikir dan berperilaku secara imbang dan penuh hikmah. Karena itu, dalam menyusun kurikulum atau program pendidikan Islam bisa bertolak dari problem yang dihadapi dalam masyarakat sebagai isi pendidikan, sedangkan proses atau pengalaman belajar peserta didik dikembangkan dengan mengkaji al Quran dan hadits. Peserta didik harus mampu merefleksikan hasil dialog antara al Quran dan hadits dengan realitas yang terjadi di masyarakat.

Keywords: reformulation, Islamic educational approach, contemporary problems 


\section{Pendahuluan}

Kejadian-kejadian mutakhir yang sering kita lihat dan dengarkan terutama tentang munculnya gerakan ekstrim dan fatalis di Islam memunculkan banyak perasaan dan berbagai macam perspektif. Perasaan masyarakat Muslim terutama sebagai masyarakat "tertuduh" tentu saja menimbulkan keresahan tersendiri dan memunculkan rekasi-rekasi emosional yang akhirnya melakukan gerakan defensif secara spontan untuk menghilangkan sebuah "citra" bahwa Islam adalah agama yang keras.Gerakan-gerakan defensif biasanya berupa "hujatan hujatan" pada kelompok-kelompok yang dianggap sebagai dalang dari kekerasan tersebut. Ada juga gerakan yang sifatnya memaklumi gerakan tersebut, sebagai bentuk perlawanan global Islam yang selama ini terlihat secara "nyata" teraniaya dan tertindas oleh mainstream demokrasi yang pada akhirnya menggiring paradigma baru tentang isu isu kemanusiaan.

Pada saat ini agama seolah-olah dianggap sebagai sistem kepercayaan yang mampu merusak mental manusia, karena dengan agama manusia menjadi ganas dan seakan-akan tiada solusi selain dengan bentuk kekerasan. Simbol simbol Islam dimanipulasi kelompok-kelompok yang berkepentingan baik di dalam diri Islam sendiri maupun di luar Islam untuk mengeksekusi beberapa keputusan yang menguntungkan kelompok kelompok tersebut. Saya mencurigai adanya beberapa kepentingan perebutan kekuasaan dan pengaruh demi menguasai modal-modal abadi yang berada pada tempat-tempat strategis untuk melanggengkan hegemoni kelompok tersebut.

Pendidikan Islam menjadi isu yang strategis apakah menjadi solusi atau malah yang menciptakan manusia-manusia yang tidak mengenal kompromi, emosi, penghancur, pemarah dalam menyelesaikan problem yang dihadapinya. Bagaimanapun juga fenomena "kejahatan" manusia di atas hampir semuanya dieksekusi oleh lulusan lembaga-lembaga yang "menjual" simbol-simbol Islam di dalamnya. Islam menjadi komoditas yang luar biasa untuk mempengaruhi seseorang untuk melakukan segala cara demi kepentingan kelompok itu sendiri.

\section{Problem Kontemporer}

Di dunia sekarang ini setidaknya ada tiga masalah krusial yang harus diperhatikan dalam pendidikan Islam. Pertama, adalah krisis kemanusiaan, bagaimana dengan hak asasi manusia yang masih menjadi problem hampir di semua lini kehidupan. Kedua, adalah masalah alam. Alam kita sekarang tampaknya sudah tidak ramah kepada manusia dan hampir semuanya 
berjalan tidak wajar. Yang ketiga adalah krisis ketuhanan, ini sebenarnya yang paling utama, manusia sudah tidak lagi menjalankan mekanisme kehidupan ini sesuai dengan aturan yang di buat Tuhan, manusia terlalu percaya diri menganggap dirinya mampu memecahkan semua problem yang terjadi di dunia, sehingga kepasrahan kepada Tuhan sangatlah lemah. Kekerasan yang mengatasnamakan agama seperti teror teror atas nama Tuhan hampir terjadi pada semua kehidupan beragama (Amrullah, 2014: 96).

Ketidakjujuran yang dilakukan lembaga pendidikan selama ini akan membentuk kepribadian anak didik yang selalu ingin memperoleh sesuatu secara instan dan hal itu dilakukan secara terus menerus yang akhirnya menjadi karakter hidup serba tercukupi. Karakter manusia instan seperti ini sangat bahaya, karena mudah sekali dipengaruhi oleh lingkungan sekitarnya atau bahkan kelompok-kelompok tertentu yang berusaha mencapai kepentingannya dengan cara apa saja.

Fenomena anak terjerat masalah hukum di Wonosobo akhir-akhir ini juga dinilai sudah memprihatinkan. Anak-anak di bawah umur di Kabupaten Wonosobo banyak yang sudah terlibat tindak pidana, misalnya pencurian kendaraan bermotor. "Pemicunya bukan sekadar kebutuhan ekonomi lantas mencuri, melainkan hanya untuk gaya-gayaan di depan temannya," kata Suyatno. Selain itu, faktor keberanian anak untuk melakukan tindak melawan hukum juga dipicu kurangnya kepedulian dari lingkungan sekitar mereka (NN, 2016).

Fenomena mutakhir yang menggambarkan gerakan ekstrim seperti pengeboman yang ada di Jakarta ternyata dilakukan oleh anak usiaremaja yaitu sekitar usia 20. Tampaknya juga ada gerakan perekrutan anak-anak sekolah untuk menjadi "pengantin bom" dengan cara mempersuasi pikiran mereka dengan hal-hal yang instan dan menjanjikan bagi mereka, sehingga mereka mengikuti segala sesuatu yang diperintahkan oleh majikannya. Belum lagi fenomena klasik yang hingga kini masih menjadi "trending topic" terutama di dunia maya yaitu fenomena "takfiri" yaitu pengkafiran pada kelompok kelompok yang berseberangan dengan keyakinannya yang dianutnya. Tentus aja fenomena takfiri ini akan berujung pada gaya hidup sosial masyarakat yang serba tidak toleran terhadap sesama, kehidupan bertetangga akan menjadi rusak, bahkan mungkin tidak akan lagi ada suasana seperti kerja bakti, gotong royong yang merupakan identitas luhur bangsa Indonesia. 


\section{Redefinisi Kembali Makna Pendidikan}

Untuk mendefiniskan kembali pendidikan Islam, maka yang harus kita kaji adalah fenomena mutakhir manusia dengan segala potensi dan aktivitasnya dan bagaimana konsep Islam dan interpretasi masyarakat Islam terhadap realitas tersebut.

Mungkin itu adalah satu kasus dari sekian kasus yang terjadi, dan itu menandaskan bahwa manusia modern ini membutuhkan transaksi yang instan untuk mencukupi kebutuhannya sebagai manusia yang ingin diakui eksistensinya sebagai mahluk yang mulya di muka bumi ini sebagai bentuk kebertahanan mereka di muka bumi ini. Islam sendiri meniscayakan upaya manusia itu dengan ayat-ayat al Quran yang menyatakan bahwa:

"Allah akan mengangkat orang-orang yang beriman dari kalian dan orang yang diberi ilmu beberapa derajat dan Allah Maha Waspada dengan apa-apa yang kamu kerjakan" (QS. al Mujadalah: 11).

Selain itu juga hadits Nabi Muhammad SAW yang diriwayatkan Bukhari menyatakan bahwa:

"Barangsiapa yang menginginkan dunia, maka hendaklah dia memiliki ilmu, barangsiapa yang menginginkan akhirat maka hendaklah ia memiliki ilmu, dan barangsiapa yang menginginkan keduanya maka hendaklah ia memiliki ilmu"(HR. Bukhari).

Ayat dan hadits diatas tentunya memiliki efek penafsiran yang bermacammacam, bagi seorang yang berkecimpung di dunia enterpreunership, maka ayat dan hadits diatas dimaknai bahwa Islam memerintahkan bahwa kaum muslim harus kaya raya, dan syarat memperoleh kekayaan itu harus dibekali dengan ilmu berupa pengamalan dan pengalaman menghadapi situasi yang sulit dan dia memutuskan dengan segala konsekuensinya baik untung maupun rugi. Bagi muslim yang berkecimpung di dunia pendidikan, maka ayat dan hadits tersebut bisa dimaknai dengan derajat posisi seseorang di masyarakat bisa di raih dengan ilmu pengetahuan. Maka efek yang terjadi adalah posisi dimaknai dengan jabatan jabatan tertentu atau bisa jadi kemulyaan seseorang di tengahtengah masyarakat, dan berbagai macam penafsiran lainnya yang dianggap relevan dan menguntungkan baik menguntungkan secara individu maupun menguntungkan eksistensi agama Islam sendiri.

Berbagai penafsiran dari berbagai macam perspektif itu tentunya akan memunculkan teori tentang manusia perspektif Islam. Manusia menurut Islam bisa diartikan sebagai seorang khalifah (pemimpin) yang diperintah Allah melalui RasulNya untuk menjaga dan bertanggungjawab (mas'ul) menjawab berbagai macam persoalan yang diciptakan Allah untuk mengembangkan potensi mereka sendiri. Definisi manusia diatas harus diimbangi juga dengan 
definisi pendidikan Islam yang selama ini pendidikan Islam dikonsep sebagai pengembangan potensi manusia secara total, sekarang harus ditambah lagi menjadi proses untuk menyelematkan fitrah manusia.

\section{Reformulasi Pendekatan Pendidikan Islam}

Pendidikan Islam harus mencari formula untuk mengantisipasi kejadian-kejadian yang membahayakan atas interpretasi yang "mungkin" tidak menguntungkan bagi Islam itu sendiri, karena akan merusak sendisendi kehidupan beragama. Pendidikan Islam harus mampu mencitrakan dirinya bahkan tidak hanya sekedar citra tapi mengembangkan karakter manusia dengan nilai-nilai yang rahmatan lil alamin, moderat, tidak mudah marah, logis, spiritual, dan berakhlakul karimah. Akhlakul karimah adalah alasan diutusnya Muhammad SAW sebagai Nabi dan rasul di muka bumi ini. Akhlakul karimah adalah perilaku manusia yang mampu memahami kapasitas dirinya sendiri sebagai pelaku, memahami orang dan alam lain karena efek dan konsekuensi perilakunya itu dan sadar bahwa segala perbuatannya itu akan di "adili" oleh Tuhan. Jadi seseorang yang memiliki akhlak yang mulia jika mampu menyeimbangkan dirinya, dengan orang lain, alam dan Tuhan dalam hal berperilaku, sehingga dia akan betul betul mempertimbangkan segala konsekuensi perilaku dan perkataannya tatkala berhadapan dengan orang lain dan akhirnya keputusannya betul betul bijaksana penuh dengan hikmah.

Pendidikan Islam yang berorientasi pada akhlakul karimah adalah pendidikan yang harus dikembangkan dan harus diwadahi dengan standar wawasan kemanusiaan dan kebangsaan dalam pengembangan materinya, standar pelayanan bagi guru yang mengajari siswanya, standar kesungguhan bagi siswa, standar inovasi dan inspiratif dalam system pembelajaran yang semuanya itu dibingkai dalam nilai nilai Islam sebagai nilai yang universal sesuai dengan segala kondisi dan situasi. Salah satu pendekatan yang harus digunakan adalah dengan pendekatan budaya yaitu pendekatan yang dilakukan dengan mendialogkan teks al Quran dan hadits dengan realitas empirik yang terjadi di daerah masing masing. Konsep dialogis tersebut akan melahirkan hukum hukum yang lebih "berakhlak" karena sesuai dengan karakter dan kearifan masing masing budaya. Menurut Toha Hamim mempertahankan pemahaman tekstual berarti menjadikan komunitas Muslim terisolir dari realitas sosial yang sudah berparadigma kebinekaan. Karena itu, eksplorasi terhadap ajaran Islam untuk mendapatkan pemahaman dengan cita rasa kultural, dan bukan nuansa 
legal-tekstual perlu dilakukan kehidupan sosial dengan aksentuasi perbedaan memang menjadi paradigm masyarakat dewasa ini. Tanpa kesediaan untuk hidup dalam kebinekaan tersebut, sebuah komunitas akan terperosok kedalam konflik komunal yang berkepanjangan (Hamim, 2004: 215).

Pendidikan Islam harus diarahkan kepada problem-problem aktual yang dihadapi dalam kehidupan nyata di masyarakat. Proses pendidikan atau pengalaman belajar peserta didik berbentuk kegiatan kegiatan belajar kelompok yang mengutamakan kerjasama, baik antar peserta didik, peserta didik dengan guru, maupun antara peserta didik dan guru dengan sumbersumber belajar yang lain. Karena itu, dalam menyusun kurikulum atau program pendidikan Islam bisa bertolak dari problem yang dihadapi dalam masyarakat sebagai isi pendidik, sedangkan proses atau pengalaman belajar peserta didik adalah dengan cara memerankan ilmu-ilmu dan teknologi, serta bekerja secara kooperatif dan kolaboratif, berupaya mencari pemecahan terhadap problem tersebut dengan mengkaji al Quran dan hadits kemudian peserta didik harus mampu merefleksikan hasil dialog antara al Quran dan hadits dengan realitas yang terjadi di masyarakat, refleksi tersebut tentusaja berupa kesimpulan dan rekomendasi solusi yang harus dilakukan untuk mengatasi problem tersebut. Bisa juga pendidikan Islam bertolak dari al Quran dan hadits kemudian siswa diarahkan oleh seorang guru untuk mencermati fenomena problem yang terjadi di masyarakat, kemudian siswa diajak melakukan refleksi dan harus diarahkan kepada pengembangan tehnik dan teknologi tertentu untuk mengatasi problem yang terjadi di masyarakat. Jadi pada intinya kurikulum pendidikan Islam harus di desain untuk mencetak manusia yang memiliki kepekaan sosial yang dilandasi nilai nilai Islam.

Seorang guru yang bijak hendaknya memiliki ruh (spirit) dan hikmah dalam mengajari anak didiknya dengan diberikan beberapa tantangan tantangan yang sudah diukur oleh seorang guru atas kemampuan anak didiknya seperti yang dilakukan oleh salah seorang kyai kepada tiga mahasiswa jurusan ekonomi yang kepingin magang di pondok pesantrennya, mereka ingin belajar berbisnis yang kebetulan sang kyai adalah seorang yang sukses dalam bidang bisnisnya. Sang kyai memberikan tantangan kepada tiga mahasiswa tersebut untuk membantu sang kyai dengan syarat ketiganya harus menyerahkan semua uang saku yang mereka miliki selama membantu sang kyai. Satu bulan berlalu, sang kyai memanggil ketiganya dan menanyakan apakah mereka kuat melaksanakan tantangan sang kyai? Ketiganya menjawab ya, kemudian sang kyai menanyakan lagi "Apakah selama satu bulan ini kalian menerima 
bantuan uang dari orang tua? Hanya satu mahasiswa yang menjawab tidak kyai, dan sisanya menjawab kami menerima kiriman uang dari orang tua kyai?. Kemudian sang kyai menjawab bagaimana kamu bisa bertahan pada saat tidak menerima kiriman dari orang tua?? Mahasiswa tersebut kemudian menjawab "ketika saya diberikan tantangan ini, maka saya anggap kyai memberikan peluang pada saya untuk melakukan inovasi-inovasi dan Alhamdulillah ada seseorang yang menghargai inovasi saya dan akhirnya saya bisa bertahan tanpa kiriman orang tua saya. Kemudian sang kyai berkata kepada mahasiswa tersebut "Wahai anakku kamu sudah berhasil belajar ilmu yang selama ini saya geluti, sekarang kamu pulang dan ambil uang ini dan sampaikan salamku kepada orang tuamu, adapun kalian berdua masih harus disini magang sampai kalian bisa melakukan seperti anak ini.

Kisah inspiratif seperti itu, sebenarnya bisa didesain sebagai bahan pembelajaran di dalam kelas kepada anak didiknya dengan cara internship atau menerjunkan peserta didik ke masyarakat yang menjadi sasaran proyek, serta belajar bekerja di masyarakat (work study). Manajemen kelasnya diupayakan untuk tidak terlalu terikat pada belajar di dalam kelas an sich, tetapi justru lebih banyak di luar kelas, tidak membedakan jenis kelamin dan ras, berusaha menciptakan suasana think-tank, serta membangun masyarakat (community building). Selama ini saya melihat kelas malah menciptakan kesempitan berfikir anak didik ketika belajar tentang realitas sosial dan alam raya ini, bukan berarti kelas tidak memiliki fungsi bagi pengembangan sikap dan intelektual anak didik akan tetapi seorang guru harus menempatkan materinya sesuai dengan tujuan belajarnya masing-masing.

Model-model pembelajaran dengan simulasi, bermain peran (role-playing), problem based learning mungkin juga bisa dikembangkan agar anak didik memiliki kompetensi utuh tentang realitas yang terjadi di dunia ini. Interaksi guru dan peserta didik dalam pembelajaran agama Islam harus lebih dinamis, kritis, prgresif, terbuka, bahkan bersikap proaktif dan antisipatif, juga mengembangkan nilai-nilai kooperatif dan kolaboratif, toleran, serta komitmen pada hak dan kewajiban asasi manusia. Pada tataran operasionalnya, dapat dikembangkan peace education sebagai model pendidikan. Peace education adalah model pendidikan yang mengupayakan pemberdayaan masyarakat agar mereka mampu mengatasi konflik atau masalahnya sendiri dengan cara kreatif dan tidak dengan cara kekerasan. Pelaksanaannya dapat berupa belajar kelompok (learning together), sehingga peserta didik terlatih memecahkan persoalan-persoalan bersama, dengan berbagai model transaksi sosial psikologisnya. Melalui belajar kelompok, 
peserta didik akan terlatih untuk menekan egoismenya dan terlatih untuk menghargai hak-hak orang lain (Muhaimin, 2005: 138).

Nilai nilai yang dipilih dalam peace education harus diarahkan pada konsep rahmatan lil alamin yaitu nilai kedamaian, penghargaan, cinta, toleransi, kejujuran, kerendahan hati, kerjasama, kebahagiaan, tanggungjawab, kesederhanaan, kebebasan dan persatuan. Seorang guru harus mampu menyisipkan nilai nilai tersebut pada saat mengajar dan mendesainnya dalam sebuah system pembelajaran sehingga guru bisa memantau perkembangan cara berfikir yang melahirkan sikap dan tindakan dalam kehidupan sehari hari. Kebebasan berfikir merupakan cara untuk membebaskan kehendak (iradah) dan pilihan menuju kebebasan memilih akidah, agama dan melakukan ibadah sesuai dengan keyakinan yang dianutnya. Hal ini berarti Islam membebaskan penganutnya untuk memilih madzhab yang sudah disepakati untuk melakukan aktivitasnya sesuai dengan konteks sosial yang berkembang di daerahnya masing masing.

Jadi sekolah atau lembaga pendidikan harus mampu membebaskan cara berfikir anak yang sempit karena doktrin-doktrin di dalam kelas saja menjadi berfikir yang lebih luas dan anak didik diajak untuk mengalami sendiri (learning by experience) sehingga mereka betul-betul mengetahui apa yang terjadi di luar sana dan seorang guru mengajak mereka untuk menemukan solusi solusi yang tepat untuk mengantisipasi problem tersebut. Menurut Ibnu Taymiyah pendekatan Tarbiyah (Pendidikan) harus dibarengi dengan pendekatan ta'lim (pembelajaran). Tarbiyah tidak akan berjalan tanpa ta'lim dan begitu sebaliknya ta'lim tidak akan memperoleh buahnya tanpa Tarbiyah keduanya adalah dua frame yang saling terkait (Sa'di: 2008: 183).

Pendidikan multicultural menjadi salah satu solusi selanjutnya untuk mengarahkan paradigma siswa bahwa manusia memang diciptakan berbeda-beda satu sama lainnya, karena proses-proses internalisasi yang sangat panjang maka terbentuklah budaya. Salah satu yang membentuk karakter dan budaya seseorang adalah perilaku yang dibiasakan sejak kecil yang dibingkai dengan budaya dan proses tersebut berlangsung terus menerus, maka akhirnya terbentuklah budaya. Kemudian adanya proses interaksi dan pembelajaran seseorang di masyarakat yang disebut sebagai enculturation dan socialization. Enculturation adalah proses perolehan karakter seseorang dari budaya yang memang sudah ada dan secara umum dia sangat kompeten karena menggunakan bahasanya sendiri sebagai alat memperoleh pengetahuan. Sedangkan socialization adalah proses pembelajaran secara umum akan norma norma sosial budaya tersebut. Melalui proses tersebut proses internalisasi norma sosial dan budaya bisa 
terwujud yang akhirnya terbentuklah budaya (Chinn, 2002: 7).

Problem selanjutnya yang mesti juga harus dipecahkan dalam pengembangan pendidikan Islamyaitu masalah komunikasi manusia dengan alam yang saat ini terancam terjadi komunikasi yang tidak seimbang yang menyebabkan rusaknya alam, karena ulah manusia itu sendiri. Bagaimana sebaiknya pengembangan, orientasi dan pendekatan yang harus dilakukan dalam menyikapi problem ini.

Kurikulum pendidikan Islam harus didesain integratif (tauhid) yaitu menyatukan antara ilmu pengetahuan umum dan ilmu agama. Konsep tauhid (integrasi) disini dimaknai bahwa antara manusia, alam dengan Tuhan sebenarnya satu kesatuan, karena manusia memang diciptakan dari unsurunsur alam dan alampun merupakan bagian yang tak terpisahkan dari ciptaan Allah SWT. Karenanya mengenal manusia, maka pasti akan kenal Tuhannya dan begitu juga mengenal alam pasti akan mengenal Allah.

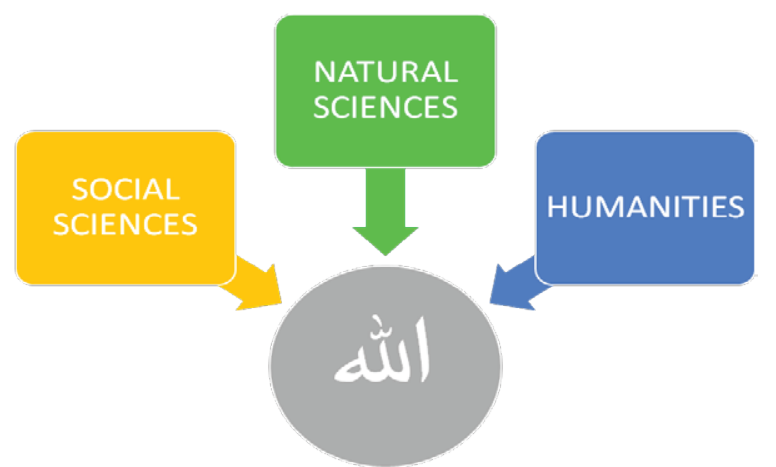

Gambar 1. Kurikulum Pendidikan Islam berbasis science dan agama.

Kesimpulannya adalah pondasi yang harus ditanam pada kurikulum Pendidikan Islam adalah berbasis science dan agama. Ibarat bibit pohon, maka bibit itu harus merupakan bibit kombinasi antara penalaran dan keyakinan. Penalaran dalam hal ini adalah logika tentu saja filsafat harus menjadi salah satu bibit dari tanaman yang bernama integrasi, sedangkan agama yang terwujudkan dalam al Quran dan hadits juga harus menjadi bibit tanaman ini dengan harapan buah yang akan diproduksi adalah buah dengan "dua rasa" yaitu rasa agama dan ilmu pengetahuan. Insan yang diharapkan adalah insan yang selalu memandang bahwa segala sesuatu yang dipelajari sebagai ilmu berasal dan berawal dari Allah, bahkan ketika manusia sendiri yang 
menelaah secara mendalam dirinya sendiri, maka ia pun berasal dan berawal dari ciptaan Allah"Barangsiapa yang memahami dirinya, maka dia akan mengetahui Allah”.

Bagaimana menyatukan dua dimensi yang selama ini saling bertentangan tentunya gak mudah. Science merupakan pendekatan yang mengandalkan rasio (akal), sedangkan agama mengandalkan hati (keyakinan). Rasio sifatnya selalu meragukan dan selalu membuat hipotesis, sedangkan hati sifatnya meyakini dan selalu menyimpulkan kebenaran. Penyatuan dua dimensi ini harus dilakukan searah dengan paradigma integrasi yang tentunya keduanya memiliki kekuatan dan kelamahannya masing masing, karenanya ada beberapa pendekatan yang perlu dilakukan, yaitu menjadikan dua dimensi itu menjadi satu siklus kebenaran. Kebenaran tidak akan bisa didapatkan jika tidak melalui siklus ini. Siklus ini mungkin bisa diberi nama siklus integrasi. Siklus integrasi ini terdiri dari (1) penalaran, (2) sintesis, (3) simpulan, (4) pemberian nama, (5) keyakinan.

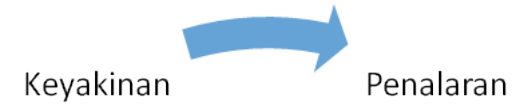

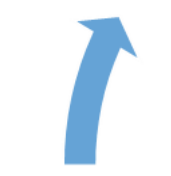

Pemberian

Nama

\section{Penalaran}

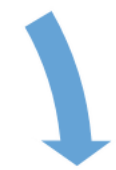

Sintesis

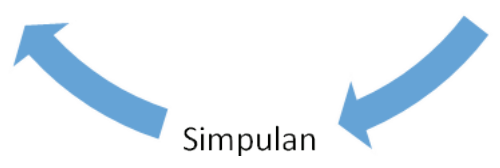

Gambar 2. Siklus integrasi

Siklus integrasi ini bisa dimulai dari pernyataan scientific misalnya dengan "lihatlah, amatilah, cobalah, ujilah" kemudian dilanjutkan dengan "Bandingkan dengan....(konsep kebenaran: dalam hal adalah al Quran ), “Temukan nilai nilai al Quran di dalamnya”, kemudian dilanjutkan dengan "Coba simpulkan pesan apa yang termuat dalam fenomena diatas jika dikaitkan dengan al Quran ", kemudian berikan nama pada fenomena tersebut, yang terakhir adalah "Apakah sekarang anda yakin dengan al Quran? 
Model di atas masih tawaran penulis yang mungkin bisa dikembangkan lagi sampai akhirnya pendidikan Islam akan selalu mengantisipasi problemproblem kemanusiaan yang akan terus melanda seiring dengan zaman.

\section{Simpulan}

Problem yang terjadi di muka bumi ini akan selalu ada sepanjang zaman, Islam sebagai agama yang mengajarkan nilai-nilai kebaikan seyogyanya juga harus mengantisipasi berbagai masalah yang terjadi. Di dunia sekarang ini setidaknya ada tiga masalah krusial yang harus diperhatikan dalam pendidikan Islam. Pertama, adalah krisis kemanusiaan, bagaimana dengan hak asasi manusia yang masih menjadi problem hampir di semua lini kehidupan. Kedua, adalah masalah alam. Alam kita sekarang tampaknya sudah tidak ramah kepada manusia dan hampir semuanya berjalan tidak wajar, yang ketiga adalah krisis ketuhanan, ini sebenarnya yang paling utama, menusia sudah tidak lagi menjalankan mekanisme kehidupan ini sesuai dengan aturan yang dibuat Tuhan, manusia terlalu percaya diri menganggap dirinya mampu memecahkan semua problem yang terjadi di dunia, sehingga kepasrahan kepada Tuhan sangatlah lemah. Kekerasan yang mengatasnamakan agama seperti terror-teror atas nama Tuhan hampir terjadi pada semua kehidupan beragama.

Islam sudah terbukti ikut andil dalam menyelesaikan tiga problem besar diatas, terutama dalam pengembangan kurikulum pendidikan Islam yang harus diarahkan pada penyelamatan fitrah manusia dan harus diarahkan pada pengembangan integrasi antara Tuhan, manusia dan alam. Pengembangan kurikulum pendidikan Islam tidak hanya pada tataran konsep akan tetapi sampai terwujud sebuah program pembelajaran kreatif dan inspiratif yang bisa diterapkan dalam sebuah sistem yang baik.

\section{Daftar Pustaka}

Amrullah, A. M. 2014. UIN Maliki Menuju World Class University, Saatnya Menjadi Rahmat Bagi Masyarakat Dunia. In TIM, Reorientasi Tradisi Perguruan Tinggi Islam. Malang: UIN Pers.

Chinn, D. M. 2002. Multicultural Education in a Pluralistic Society (Sixth ed.). New Jersey: Merril Prentice Hall.

Hamim, T. 2004. Islam dan NU di Bawah Tekanan Problematika Kontemporer; Dialektika Kehidupan Politik, Agama, Pendidikan dan Sosial Masyarakat Muslim. Surabaya: Diantama. 
Muhaimin. 2005. Pengembangan Kurikulum PAI di Sekolah, Madrasah, dan Perguruan Tinggi. Jakarta: Rajawali Pers.

NN. 2016. Retrieved 2 2016, from http://www.regional.kompas.com

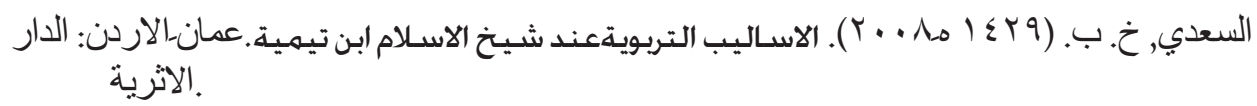

